\title{
PENGARUH EDUKASI GIZI TERHADAP PERUBAHAN PENGETAHUAN, AKTIVITAS SEDENTARY DAN ASUPAN ZAT GIZI PADA REMAJA OVERWEIGHT DAN OBESITAS DI SMA NEGERI 2 KOTA SORONG
}

\author{
Lasupu $^{1}$, Irma Susan Paramita ${ }^{2}$ \\ ${ }^{1,2}$ Jurusan Gizi Politeknik Kesehatan Kementerian Kesehatan Sorong, Papua Barat \\ Email : abriliannita@gmail.com
}

\begin{abstract}
Obesity is a problem worldwide due to increasing prevalence in adults and adolescents both in developed countries and in developing countries.

The purpose of this study was to determine the effect of nutrition education to changes in knowledge, sedentary activity and nutrient intake in adolescents at SMAN 2 Sorong.

This type of research is pre-experimental design. Sampling was done by purposive sampling using the formula Lameshow. The research sample of 38 categories of nutritional status of overweight and obesity. Then performed a pretest for all respondents and given nutrition education using slides, leaflets and sms (short message service). Data measured respondents' knowledge at the time of pre-test and post test using questionnaires knowledge. Data food intake was measured using 24-hour recall questionnaire. Neither the sedentary lifestyle measurement data using questionnaires sedentary life style.

The results showed Providing nutrition education significantly influence changes in knowledge adolescent overweight and obesity SMA N 2 Sorong city with an increase of 0.72 ( $\Delta$ mean) with score $p=0.12$. the provision of nutrition education influence the change sedentary activity adoloscent overweight and obesity SMA N 2 Sorong city with a drop of 0,1 ( $\Delta$ mean) but the result was not significant $(p=0,210)$. The provision of nutrition education had no effect on changes in energy intake $(p=0.06)$, carbohydrates $(p=0.35)$ and fat $(p=0.07)$ adolescent overweight and obesity SMA $N 2$ Sorong city. The provision of nutrition education affect the changes in fiber intake adolescent overweight and obesity to increase fiber intake of 0.16 (Amean) but the result was not significant $(p=0.12)$.
\end{abstract}

Keywords: Nutrition Education, Knowledge, sedentary activity, intake of nutrients, Overweigth.

\section{ABSTRAK}

Obesitas menjadi masalah diseluruh dunia karena prevalensinya yang meningkat pada orang dewasa dan remaja baik di negara maju maupun di negara berkembang.

Tujuan Penelitian ini adalah untuk mengetahui pengaruh edukasi gizi terhadap perubahan pengetahuan, aktivitas sedentary dan asupan zat gizi pada remaja di SMA Negeri 2 Kota Sorong.

Jenis penelitian yang digunakan adalah rancangan pre-eksperimental. Pengambilan sampel dilakukan secara purposive sampling dengan menggunakan rumus Lameshow.Sampel penelitian sebesar 38 dengan kategori status gizi overweight dan obesitas. Selanjutnya dilakukan pretest pada semua responden lalu diberikan edukasi gizi dengan menggunakan slide, leaflet dan sms (short message service). Data pengetahuan responden di ukur pada saat pre test dan post test dengan menggunakan kuesioner pengetahuan. Data asupan makan diukur menggunakan kuesioner recall 24 jam. Begitupula dengan data pengukuran gaya hidup sedentary dilakukan dengan menggunakan kuesioner sedentary life style.

Hasil penelitian menunjukkan pemberian edukasi gizi berpengaruh secara signifikan terhadap perubahan pengetahuan remaja overweight dan obesitas remaja di SMA Negeri 2 Kota Sorong mengalami peningkatan sebesar $0,72(\Delta$ mean) dengan nilai $\mathrm{p}=0,000$. Pemberian edukasi gizi berpengaruh terhadap perubahan aktivitas sedentary remaja overweight dan obesitas dengan penurunan sebesar $0,1(\Delta$ mean $)$, Namun hasilnya tidak signifikan $(\mathrm{p}=0,210)$. Pemberian edukasi gizi tidak berpengaruh terhadap perubahan asupan energy $(\mathrm{p}=0,06)$, karbohidrat $(\mathrm{p}=0,35)$ dan lemak $(\mathrm{p}=0,07)$ remaja overweight dan obesitas. Pemberian edukasi gizi berpengaruh terhadap perubahan asupan serat remaja overweight dan obesitas SMA Negeri 2 Kota Sorong dengan peningkatan asupan serat sebesar 0,16 ( $(\Delta$ mean $)$ namun hasilnya tidak signifikan $(\mathrm{p}=0,12)$

Kata Kunci : Edukasi Gizi, Pengetahuan, Aktivitas sedentary, Asupan Zat gizi, Overweigth. 


\section{PENDAHULUAN}

Keberhasilan

pembangunan nasional khususnya dalam bidang gizi dan kesehatan, beberapa tahun belakangan ini berdampak baik bagi penurunan jumlah penderita kasus gizi kurang di Indonesia dan dunia. Namun keberhasilan tersebut diikuti oleh peningkatan prevalensi gizi lebih pada masyarakat (Staggers et al, 2012).

Obesitas adalah salah satu tantangan kesehatan masyarakat yang paling serius dari abad ke-21. Masalahnya global dan terus mempengaruhi banyak negara-negara berpenghasilan rendah dan menengah, khususnya di daerah perkotaan. Prevalensi telah meningkat pada tingkat yang mengkhawatirkan (WHO, 2013).

Prevalensi obesitas terus mengalami peningkatan dari waktu ke waktu. Tidak hanya di Negara maju tapi juga merambah ke negara-negara berkembang. Tidak hanya terjadi pada

\section{SUBJEK DAN METODE}

\section{Jenis Penelitian}

Penelitian ini merupakan jenis penelitian pre eksperimen untuk melihat pengaruh edukasi yang diberikan terhadap perubahan pengetahuan dan asupan zat gizi pada remaja overweight dan obesitas. Desain penelitian menggunakan Quasi eksperimen dengan bentuk rancangan pretest-postest dalam suatu kelompok (one group design pretest-postest), dimana siswa SMA (remaja) dengan status gizi overweight dan obesitas diberi edukasi gizi. Edukasi ini diharapkan dapat memberi efek positif terhadap perubahan pengetahuan, aktivitas sedentary dan asupan zat gizi.

\section{Lokasi Penelitian}

Lokasi penelitian dilakukan di SMA Negeri 2 Kota Sorong pada bulan November 2017

Perspective : Redefinising Obesity and its Treatment, 2000)

\section{Asupan energy}

Sejumlah kandungan energi dari makanan dan minuman yang dikonsumsi remaja. orang dewasa tapi juga terjadi pada anakanak dan remaja.

National Health and Nutritional

Examination Survey (NHANES) mengumpulkan data antara tahun 20032006, hasilnya menunjukkan bahwa di Amerika Serikat, pada remaja usia 11-19 tahun prevalensi overweight (kelebihan berat badan) adalah 31,4\% dan prevalensi obesitas adalah 17,6 \%

(Masyita, 2015).

Hasil riskesdas pada tahun 2007 prevalensi obesitas pada remaja usia 15 tahun ke atas di Indonesia adalah sebesar 19,1 \%. Di Provinsi Papua Barat prevalensi Berat badan lebih (overweight) pada remaja usia lebih dari 15 tahun sebesar 9,6\% sedangkan prevalensi obesitas pada remaja usia lebih dari 15 tahun sebesar 13,4\%. Prevalensi tersebut berada di atas prevalensi nasional Indonesia yaitu sebesar $8,8 \%$ (Berat badan lebih/overweight) dan $10,3 \%$ (Obesitas).

\section{Sampel}

Sampel dalam penelitian ini adalah remaja dengan status gizi overweight dan obesitas berjumlah 38 siswa

Teknik pengambilan sampel penelitian diambil dengan purposive sampling.

\section{Defenisi Operasional}

Definisi operasional adalah untuk membatasi ruang lingkup atau pengertian dan variabel-variabel yang diteliti atau diamati (Notoatmojo, 2012).

\section{Obesitas}

Suatu keadaan akumulasi energi yang berlebihan dalam bentuk lemak tubuh yang diukur berdasarkan Indeks Massa Tubuh (IMT) (The Asia Pasific

\section{Asupan Karbohidrat}

Sejumlah kandungan KH dari makanan dan minuman yang dikonsumsi remaja

\section{Asupan Lemak}


Sejumlah kandungan lemak dari makanan dan minuman yang dikonsumsi remaja.

\section{Asupan serat}

Sejumlah kandungan serat dari makanan dan minuman yang dikonsumsi remaja.

\section{Pengetahuan responden}

Pengetahuan yang dimaksukan yaitu responden mengeahui tentang overweight, perilaku makan, serta aktifitas sedentary

7. Aktivitas sedentary

\section{HASIL PENELITIAN}

\section{Gambaran Umum Lokasi Penelitian} Penelitian ini telah dilakukan di SMA Negeri 2 Kota Sorong. SMA Negeri 2 merupakan salah satu sekolah negeri yang terakreditasi A. Sekolah ini berlokasi di jalan Sungai Maruni, Kecamatan Sorong Timur Kelurahan Sawagumu.

Jumlah keseluruhan siswa SMA

Negeri 2 Kota Sorong adalah 280 siswa. karakteristik remaja berdasarkan karakteristik orang tua responden (tingkat pendidikan orang tua, tingkat pekerjaan orang tua), uang jajan responden.

\section{Data Khusus}

a. Analisa univariat
Aktivitas yang cenderung diam dan duduk atau di depan layar tanpa banyak bergerak yang dilakukan oleh responden dalam sehari seperti menonton televisi atau video, bermain komputer, atau video game, duduk dan mendengarkan musik, duduk dan berbicara di telpon/handphone (Norman, Gregory J, et al, 2005)

\section{Instrumen dan Cara Pengumpulan Data}

Instrumen penelitian yang digunakan dalam penelitian ini adalah format isian yang berisi semua data yang dibutuhkan dalam penelitian yang diisi sendiri oleh Peneliti

Dari jumlah populasi keseluruhan yang berjumlah 280 siswa.

\section{Data Umum}

Data umum merupakan data tentang karakteristik responden dimana responden didalam penelitian ini adalah remaja yang dirangkum dalam beberapa kriteria yaitu

Analisa univariat adalah menganalisa data yang akan diuji yaitu masing-masing variabel independent dan variabel dependent kemudian didistribusikan kedalam tabel distribusi frekuensi. Adapun data khusus sebagai berikut:

1) Distribusi Frekuensi berdasarkan Status Gizi Responden.

Tabel 1. Distribusi Responden berdasarkan Status Gizi (IMT/U)

\begin{tabular}{ccc}
\hline Variabel & $\begin{array}{c}\mathbf{N}= \\
\mathbf{3 6}\end{array}$ & $\mathbf{\%}$ \\
\hline Status Gizi & & \\
Overweight & 14 & 38,9 \\
Obesitas & 22 & 61,1 \\
\hline
\end{tabular}

Sumber: Data primer, 2016

Tabel 1 menunjukkan jumlah responden yang berstatus gizi overweight (gemuk) adalah 14 responden $(38,9 \%)$ dan

2) Distribusi Frekuensi berdasarkan Pegetahuan Responden yang berstatus gizi obesitas (sangat gemuk) adalah 22 responden $(61,1 \%)$. 
Tabel 2. Distribusi Tingkat Pengetahuan Responden Sebelum dan Sesudah Edukasi Gizi

\begin{tabular}{ccccc}
\hline \multirow{2}{*}{ Nilai } & \multicolumn{2}{c}{ Pre test } & \multicolumn{2}{c}{ Post test } \\
\cline { 2 - 5 } & $\mathrm{n}=36$ & $\%$ & $\mathrm{n}=36$ & $\%$ \\
Kurang & 23 & 63,9 & 7 & 19,4 \\
Cukup & 13 & 36,1 & 19 & 52,8 \\
Baik & 0 & 0,0 & 10 & 27,8 \\
\hline
\end{tabular}

Sumber: Data primer, 2016

Tabel 2 menunjukkan bahwa sebelum pemberian edukasi gizi sebanyak 13 responden $(36,1 \%)$ memiliki pengetahuan yang cukup dan meningkat menjadi 19 responden $(52,8 \%)$ setelah pemberian edukasi. Responden yang memiliki pengetahuan kurang sebanyak 23 responden
$(63,9 \%)$ dan menjadi 7 responden $(19,4 \%)$ setelah pemberian edukasi. Tidak ada responden yang memiliki pengetahuan baik $(0 \%)$ sebelum pemberian edukasi namun setelah edukasi menjadi 10 responden yang berpengetahuan baik

$(27,8 \%)$

3) Distribusi Frekuensi berdasarkan Asupan Zat

Gizi

Tabel 3 Distribusi Asupan Zat Gizi Responden Sebelum dan Sesudah Edukasi Gizi

\begin{tabular}{|c|c|c|c|c|}
\hline \multirow{2}{*}{$\begin{array}{c}\text { Asupan Zat } \\
\text { Gizi }\end{array}$} & \multicolumn{2}{|c|}{ Pre Test } & \multicolumn{2}{|c|}{ Post Test } \\
\hline & $\mathrm{n}=36$ & $\%$ & $\mathrm{n}=36$ & $\%$ \\
\hline \multicolumn{5}{|l|}{ Energi } \\
\hline Kurang & 10 & 27,8 & 11 & 30,6 \\
\hline Cukup & 18 & 50,0 & 11 & 30,6 \\
\hline Lebih & 8 & 22,2 & 14 & 38,9 \\
\hline \multicolumn{5}{|l|}{ Karbohidrat } \\
\hline Kurang & 7 & 19,4 & 6 & 16,7 \\
\hline Cukup & 24 & 66,7 & 22 & 61,1 \\
\hline Lebih & 5 & 13,9 & 8 & 22,2 \\
\hline \multicolumn{5}{|l|}{ Lemak } \\
\hline Kurang & 5 & 13,9 & 9 & 25,0 \\
\hline Cukup & 9 & 25,0 & 12 & 33,3 \\
\hline Lebih & 22 & 61,1 & 15 & 41,7 \\
\hline \multicolumn{5}{|l|}{ Serat } \\
\hline Kurang & 22 & 61,1 & 18 & 50,0 \\
\hline Cukup & 7 & 19,4 & 12 & 33,3 \\
\hline Lebih & 7 & 19,4 & 6 & 16,7 \\
\hline
\end{tabular}

Sumber: Data primer, 2016

Tabel 3 menggambarkan sebagian besar asupan energy responden cukup sebelum pemberian edukasi gizi yaitu sebanyak 18 responden $(50,0 \%)$ dan menurun menjadi 11 responden $(30,6 \%)$ setelah pemberian edukasi gizi.

Asupan karbohidrat responden sebagian besar cukup sebelum pemberian edukasi gizi yaitu sebanyak 22 responden $(66,7 \%)$ dan menurun menjadi 22 responden $(61,1 \%)$ setelah pemberian edukasi gizi.

Asupan lemak responden sebagian besar lebih sebelum pemberian edukasi gizi yaitu sebanyak 22 responden $(66,1 \%)$ dan menurun menjadi 15 responden $(41,7 \%)$ setelah pemberian edukasi gizi. 
Asupan serat responden sebagian besar kurang sebelum pemberian edukasi gizi yaitu sebanyak 22 responden (66,7\%)

4) Distribusi Frekuensi berdasarkan Aktivitas Sedentary

Tabel 4 Distribusi Aktivitas Sedentary Responden Sebelum dan Sesudah Edukasi Gizi

\begin{tabular}{llrlr}
\hline \multicolumn{1}{c}{$\begin{array}{c}\text { Aktivitas } \\
\text { sedentary }\end{array}$} & \multicolumn{2}{c}{ Pre test } & \multicolumn{2}{c}{ Post test } \\
\cline { 2 - 5 } & $\mathrm{n}=$ & $\%$ & $\mathrm{n}=$ & $\%$ \\
& 36 & & 36 & \\
$\leq \mathbf{4 j a m}$ & 13 & 36,1 & 17 & 47,2 \\
$\begin{array}{l}\text { (tidak } \\
\text { sedentary) }\end{array}$ & & & & \\
$\begin{array}{l}>\text { 4 jam } \\
\text { (sedentary) }\end{array}$ & 23 & 63,9 & 19 & 52,8 \\
\hline
\end{tabular}

Sumber: Data primer, 2016

Tabel 4 menunjukkan responden yang memiliki aktivitas sedentary sebelum pemberian edukasi gizi adalah 23 responden $(63,9 \%)$ dan menurun menjadi 19 responden $(52,8 \%)$ setelah pemberian edukasi gizi. Responden yang tidak memiliki aktivitas

2) Hasil Analisis Asupan Zat Gizi Responden Sebelum dan sesudah Edukasi Gizi dan menurun menjadi 18 responden $(50,0 \%)$ setelah pemberian edukasi gizi.

sedentary sebelum pemberian edukasi gizi adalah 13 responden $(36,1 \%)$ dan meningkat menjadi 17 responden $(47,2 \%)$ setelah pemberian edukasi gizi.

b. Analisis bivariat

Pada analisis bivariat akan disajikan hubungan antara masing-masing variabel independen dengan dependen untuk melihat hubungan antara variabel indipenden dan variabel dependen

1) Hasil Analisis Tingkat pengetahuan Sebelum dan Sesudah Edukasi Gizi.

Tabel 5 menunjukkan ada peningkatan pengetahuan setelah pemberian edukasi sebanyak 0,72 . Nilai $p$ menunjukkan hasil bahwa ada perbedaan yang signifikan antara pengetahuan sebelum dan sesudah pemberian edukasi gizi dengan nilai $\mathrm{p}=0,000(\mathrm{p}<0,05)$.

Tabel 6 Hasil Analisis Asupan Zat Gizi Responden Sebelum dan Sesudah Edukasi Gizi

\begin{tabular}{lcccc}
\hline Asupan Zat Gizi & Mean & SD & $\Delta$ mean & P value \\
\hline Pre Test & & & & \\
$\quad$ Energi & 1,72 & 0,81 & 0,36 & 0,06 \\
$\quad$ Karbohidrat & 1,94 & 0,58 & 0,11 & 0,35 \\
Lemak & 1,62 & 0,87 & 0,11 & 0,07 \\
$\quad$ Serat & 1,68 & 0,80 & 0,16 & 0,12 \\
Post Test & & & & \\
Energi & 2,08 & 0,84 & 0,36 & 0,06 \\
Karbohidrat & 2,05 & 0,62 & 0,11 & 0,35 \\
Lemak & 1,94 & 0,76 & 0,11 & 0,07 \\
Serat & 1,84 & 0,83 & 0,16 & 0,12 \\
\hline
\end{tabular}

Sumber: Data primer, 2016

Tabel 6 menunjukkan ada peningkatan asupan energy sebanyak 0,36 , $(\mathrm{p}=0,06)$ peningkatan asupan karbohidrat sebanyak $0,11(\mathrm{p}=0,35)$, peningkatan asupan

3) Hasil Analisis Aktivitas Sedentary

Responden Sebelum dan Sesudah Edukasi Gizi

Tabel 7 Hasil Analisis Aktivitas Sedentary Responden Sebelum dan Sesudah Edukasi Gizi

\begin{tabular}{lllll}
\hline Aktivitas & Mean & SD & $\Delta$ & P \\
\hline
\end{tabular}

lemak sebanyak $0,11 \quad(p=0,07)$ dan peningkatan asupan serat sebanyak 0,16 $(p=0,12)$ setelah pemberian edukasi gizi, namun hasilnya tidak signifikan.

\begin{tabular}{lllll}
\hline sedentary & & & mean & value \\
\hline Pre Test & 1,63 & 0,48 & 0,1 & 0,210 \\
Post Test & 1,52 & 0,50 & & \\
\hline
\end{tabular}

Sumber: Data primer, 2016

Tabel 7 menunjukkan ada penurunan aktivitas sedentary setelah pemberian edukasi sebanyak 0,1 namun nilai $\mathrm{p}$ menunjukkan hasil bahwa tidak ada 
perbedaan yang signifikan antara pengetahuan sebelum dan sesudah pemberian edukasi gizi dengan nilai $\mathrm{p}=$ $0,210$ ( $\mathrm{p}>0,05)$.

\section{PEMBAHASAN}

\section{Pengetahuan Responden}

Tabel 4.5 dan 4.6 menunjukkan pengaruh edukasi terhadap perubahan pengetahuan responden yaitu dengan adanya peningkatan pengetahuan setelah pemberian edukasi sebanyak 0,72 . Nilai $p$ menunjukkan hasil bahwa ada perbedaan yang signifikan antara pengetahuan sebelum dan sesudah pemberian edukasi gizi dengan nilai $\mathrm{p}=0,000 \quad(\mathrm{p}<0,05)$. Menurut peneliti adanya peningkatan pengetahuan pada responden Sering masalah gizi timbul dikarenakan ketidaktahuan responden dan kurangnya informasi mengenai gizi. Terbentuknya perilaku yang baru dari pengetahuan terhadap stimulasi berupa materi atau objek tentang sesuatu yang akan menimbulkan pengetahuan baru pada subjek tersebut dan selanjutnya menimbulkan respon yang lebih jauh yaitu berupa tindakan. Namun, pengetahuan yang cukup tidak menjamin seseorang berprilaku yang sama seperti apa yang diketahui. Dapat dikatakan bahwa dalam hasil penelitian ini, tingkat pengetahuan responden masuk dalam kategori tahu (know) yang diartikan sebagai mengingat suatu materi yang telah di pelajari sebelumnya. Termasuk ke dalam pengetahuan tingkat ini adalah mengingat kembali (recall) terhadap sesuatu yang spesifik dari keseluruhan bahan yang dipelajari atau rangsangan yang telah diterima (Notoatmodjo, 2010).

\section{Asupan Zat Gizi}

Tabel 4.8 menunjukkan ada peningkatan asupan energy sebanyak 0,36, $(\mathrm{p}=0,06)$ peningkatan asupan karbohidrat sebanyak $0,11(\mathrm{p}=0,35)$, peningkatan asupan lemak sebanyak $0,11 \quad(p=0,07)$ dan peningkatan asupan serat sebanyak 0,16 $(\mathrm{p}=0,12)$ setelah pemberian edukasi gizi, namun hasilnya tidak signifikan.

Konsumsi energi dari makanan dibutuhkan untuk melakukan aktivitas sehari-hari. Kebutuhan energi pada makanan selain untuk aktivitas fisik sehari-hari juga terjadi proses pertumbuhan fisik yang pesat kemungkinan dsebabkan karena peneliti memaksimalkan media cetak (leaflet edukasi) dan media elektronik (slide dan sms) dalam pemberian edukasi gizi pada remaja obesitas di SMA $\mathrm{N} 2$ Kota Sorong.

Pengetahuan merupakan hasil dari tahu dan ini terjadi setelah seseorang melakukan penginderaan terhadap suatu obyek tertentu. Penginderaan ini terjadi melalui panca indera manusia yaitu indera penglihatan, pendengaran, penciuman, rasa dan raba. Sebagian besar pengetahuan manusia diperoleh melalui mata dan telinga. Pengetahuan merupakan domain yang sangat penting untuk terbentuknya perilaku seseorang (Notoatmodjo, 2010).

serta perubahan bentuk dan susunan jaringan tubuh yang membutuhkan banyak energi.

Terdapat tiga sumber energi dalam tubuh, yaitu karbohidrat, lemak, dan protein. Di dalam tubuh, zat gizi tersebut dipecah menjadi energy dan energi yang dihasilkan dari setiap gram karbohidrat adalah empat kalori, lemak sembilan kalori, dan protein empat kalori (Devi, 2010).

Energi dalam tubuh berfungsi untuk metabolisme basal, yaitu energi yang dibutuhkan pada waktu beristirahat, kemudian specific dynamic action (SDA), yaitu energi yang diperlukan untuk mengolah makanan itu sendiri, untuk aktivitas jasmani, berpikir, pertumbuhan, dan pembuangan sisa makanan. Kekurangan energi akan menghambat semua aktivitas di dalam tubuh (Devi, 2010).

Kelebihan energi terjadi apabila konsumsi energi melalui makanan melebihi energi yang dikeluarkan. Kelebihan energi ini akan diubah menjadi lemak tubuh. Akibatnya, terjadi berat badan lebih atau kegemukan. Kegemukan bisa disebabkan oleh kebanyakan makan dalam hal ini jenis karbohidrat, lemak maupun protein. (Almatsier, 2009).

Karbohidrat merupakan sumber energi utama bagi manusia. Setiap satu gram karbohidrat menghasilkan empat kalori. Menurut anjuran WHO (1990) adalah 55-75 persen dari total konsumsi energy diutamakan berasal dari gula sederhana. Padi-padian, umbi-umbian, kacang-kacangan kering dan hasil olahan seperti bihun, mie, 
roti, dan tepung dapat dimanfaatkan sebagai sumber karbohidrat (Achadi,2007).

Salah satu penyebab kelebihan berat badan pada anak adalah pemilihan jenis makanan yang kurang tepat, seperti makanan yang berlemak tinggi. Faktor lain yang mungkin juga mempengaruhi adalah kebiasaan konsumsi keluarga. Konsumsi lemak yang tinggi lebih banyak ditemukan dikonsumsi oleh masyarakat kelompok menengah ke atas. Hal ini dapat disebabkan karena mereka lebih konsumtif dan lebih cenderung mengikuti trend dimana sekarang ini sangat banyak trend yang mengangkat makanan yang berlemak tinggi seperti fast food yang sangat rendah kandungan nilai gizinya.

WHO menganjurkan konsumsi lemak berkisar 15-30 persen dari total kebutuhan energi. Jumlah tersebut dianggap memenuhi kebutuhan asam lemak esensial dan membantu penyerapan vitamin larut lemak. Dari kebutuhan tersebut paling banyak 10 persen berasal dari lemak jenuh

\section{Aktivitas sedentary Responden}

Tabel 4.9 menunjukkan ada penurunan aktivitas sedentary setelah pemberian edukasi sebanyak 0,1 namun nilai $\mathrm{p}$ menunjukkan hasil bahwa tidak ada perbedaan yang signifikan antara pengetahuan sebelum dan sesudah pemberian edukasi gizi dengan nilai $\mathrm{p}=0,210$ $(p>0,05)$.

Hasil penelitian berdasarkan pada beberapa studi tentang aktivitas sedentary dan obesitas pada anak dan remaja menunjukkan bahwa intervensi pada penurunan aktivitas sedentary merupakan intervensi yang efektif untuk mengurangi aktivitas tersebut dan mengendalikan berat badan pada anak-anak dan remaja ( DeMattia, et al, 2007)

Penelitian tentang hubungan antara aktifitas fisik dan sedentari menunjukkan bahwa pada remaja, hubungan positif ditemukan antara jenis kelamin (laki-laki) dan aktifitas sedentari, sedangkan hubungan terbalik ditemukan antara jenis kelamin dan aktifitas fisik yang memadai. Etnis (Kaukasia), status sosial ekonomi, dan edukasi orang tua yang juga ditemukan berbanding terbalik dengan aktifitas sedentari pada remaja (Van Der Horst, et al, 2007) dan 3-7 persen lemak tidak jenuh dan konsumsi kolesterol dianjurkan kurang dari $300 \mathrm{mg}$ sehari (Guthrie, H.A, 1989 dalam Achadi, 2007).

Seseorang dengan pola makan mengandung serat, jarang ditemukan mengalami kegemukan. Anak yang overweight atau obesitas membutuhkan lebih makanan yang mengandung serat seperti sayur dan buah. Serat berfungsi mengontrol berat badan karena serat tidak menyumbangkan banyak energi. Serat juga memberikan efek kenyang yang lebih lama sehingga tidak cepat timbul rasa lapar (Yuliarti, 2008).

Kebutuhan serat sehari menurut Lembaga Kanker Amerika menganjurkan 2030 gram sehari. Pola makanan penduduk Indonesia umumnya kaya serat dari kacangkacangan, sayuran, maupun buah (Achadi, 2007). Tujuannya untuk menghindari kelebihan lemak, lemak jenuh dan kolesterol, gula dan natrium, serta membantu mengontrol berat badan.

Penelitian tentang karakteristik yang dapat diubah dan terkait dengan aktivitas sedentari pada remaja menunjukkan bahwa selain BMI, faktor lain yang berhubungan dengan aktivitas sedentary meliputi aktivitas fisik, dorongan orang tua dan dukungan untuk kegiatan fisik, perilaku teman dekat aktivitas fisik, dan status merokok. Penelitian ini menemukan bahwa siswa sangat terlibat dalam kegiatan di depan layar, tetapi menghabiskan waktu yang terbatas pada aktivitas sedentary yang lebih produktif, seperti membaca dan melakukan pekerjaan rumah. Mengembangkan pemahaman yang lebih baik tentang perilaku menetap sangat penting untuk mencegah dan mengurangi obesitas pada populasi remaja (Leatherdale, and Wong, 2008).

\section{KETERBATASAN PENELITIAN}

Keterbatasan penelitian memaparkan hal-hal atau variabel yang sebenarnya tercakup di dalam keluasan lingkup penelitian tetapi karena kesulitan-kesulitan metodologis atau prosedural tertentu sehingga tidak dapat dicakup di dalam penelitian dan kendali peneliti. Keterbatasan dalam penelitian ini yaitu peneliti tidak mengontrol langsung asupan makanan dan aktivitas fisik responden sehingga pengaruh 
edukasi gizi yang diberikan tidak memberikan efek yang maksimal.

\section{KESIMPULAN}

1. Pemberian edukasi gizi berpengaruh secara signifikan terhadap perubahan pengetahuan remaja overweight dan obesitas SMA Negeri 2 Kota Sorong dengan peningkatan sebesar 0,72 dengan nilai $\mathrm{p}=0,000$.

2. Pemberian edukasi gizi berpengaruh terhadap perubahan aktivitas sedentary remaja overweight dan obesitas SMA Negeri 2 Kota Sorong dengan penurunan sebesar 0,1 namun hasilnya tidak signifikan $(\mathrm{p}=0,210)$

3. Pemberian edukasi gizi tidak berpengaruh terhadap perubahan asupan

\section{REFERENSI}

1. Almatsier. 2004. Prinsip Dasar Ilmu Gizi. Jakarta: Gramedia Pustaka Utama.

2. Al Rethaiaa, A Fahmy, and Al Shwaiya. 2010. Obesity and Eating Habits Among Colellege Students in Saudi Arabia: A Cross Sectional Study. Nutrition Journal (on line) 9:39. (http://www.nutritionj.com/content/9/1/39

3. Arisman, 2004. Gizi Dalam Daur Kehidupan. Jakarta: EGC.

4. Arofah. 2010. Konsumsi Soft Drink Sebagai Faktor Risiko Terjadinya Obesitas pada Remaja Usia 15-17 Tahun (Studi Kasus di SMUN 5 Semarang). Universitas Diponegoro Repository (on line). (http://eprints.undip.ac.id, diakses tanggal 12 Desember 2012)

5. Astawan. 2008. Sehat dengan Sayuran: Panduan Lengkap Menjaga Kesehatan dengan Sayuran. Jakarta: Dian Rakyat.

6. Badrialaily. 2004. Studi Tentang Pola Konsumsi Serat pada Mahasiswa. Sktipsi tidak diterbitkan. Bogor. Institut Pertanian Bogor.

7. Banowati, dkk. 2011. Risiko Konsumsi Western Fast Food dan Kebiasaan Tidak Makan Pagi Terhadap Obesitas Remaja Studi di SMAN 1 Cirebon. Media Medika Indonesiana (on line) volume 42, Issue 2 tahun 2011. energy $(p=0,06)$, karbohidrat $(p=0,35)$ dan lemak $(\mathrm{p}=0,07)$ remaja overweight dan obesitas SMA Negeri 2 Kota Sorong.

4. Pemberian edukasi gizi berpengaruh terhadap perubahan asupan serat remaja overweight dan obesitas SMA Negeri 2 Kota Sorong dengan peningkatan asupan serat sebesar 0,16 namun hasilnya tidak signifikan $(\mathrm{p}=0,12)$

\section{SARAN}

Disarankan untuk penelitian selanjutnya sebaiknya dikontrol pula asupan makanan dan aktivitas fisik secara langsung agar efek edukasi gizi bisa memberikan hasil yang maksimal.

8. Contento. 2007. Nutrition Education, Linking Research, Theory and Practice. Canada. Jones and Bartlett Publisher

9. Franco, et all. 2008. Motivation, Self Efficacy, Physical Activity, and Nutrition In College Students : Randomized Controlled Trial of an Internet-Based Education Program. Prevention Medicine (on line), 47(4):369-377.

10.Determinats of Body weight. Journal of The American Dietetik Association (on line) volume 111, issue 3, pages 394-400.

11.Hashemipour, et all. 2011. Effect of Education on Antropometric Indices in Obese Parents and Children

12.Hastuti. 2008. Faktor Risiko Frekuensi Konsumsi Fast Food Terhadap Kejadian Kegemukan (Overweight) pada Remaja di SMA Batik I Surakarta. Tesis tidak diterbitkan. Surakarta: Universitas Muhammadiyah.

13.Lazzeri, Rossi, Pammolli, Pilato, Pozzi, and Giacchi. 2008. Underweight and Overweight Among Children and Adolescent in Tuscany(Italy). Prevalence and Short-Term Trends. Journal of Prevention Medicine an Hygiene (on line) 49 (1):13-21. http:// www.jpmh.org/, Leathar, et all. 1985. Health Education and The Media II. Edinburgh. Pergamon Press.

14.Leatherdale and Wong. 2008. Modifiable Characteristics Associated With Sedentary Behaviors Among Youth. International Journal of Pediatrics 
Obesity (on line) 3(2): 93-101. (http:/www. informahealthcare.com/jpo)

15.Litbangkes. 2008. Laporan Riset Kesehatan Dasar tahun 2007. Departemen Kesehatan Republik Indonesia

16.Litbangkes. 2011. Laporan Riset Kesehatan Dasar tahun 2010. Departemen Kesehatan Republik Indonesia

17.Litbangkes. 2014. Laporan Riset Kesehatan Dasar tahun 2013. Departemen Kesehatan Republik Indonesia
18.Lubans, et all.2010. Exploring the Mechanism of Physical Activity and Dietary Behavior Change in The Program X Inte/rvention for Adolescent. Journal of Adolescent Health (on line)', Volume 47, issue 1, pages 83-91. (http:// www.jahonline.org/) 